\title{
Práticas sociais entre línguas em contato: os empréstimos linguísticos do português à Libras
}

Social Practices between Languages in

Contact: the Loanwords from Portuguese to

Brazilian Sign Language (Libras)

Isabel Cristina Rodrigues*

Universidade do Estado do Rio de Janeiro (UERJ)

Rio de Janeiro - Rio de Janeiro / Brasil

Angela Corrêa Ferreira Baalbaki**

Universidade do Estado do Rio de Janeiro (UERJ)

Rio de Janeiro - Rio de Janeiro / Brasil

RESUMO: Este artigo discute situaçôes de contato entre o português (língua oral-auditiva) e a língua brasileira de sinais - Libras (língua espaço-visual), com o objetivo de investigar o recurso dos empréstimos linguísticos decorrentes das práticas sociais em que se encontram inseridos surdos falantes de Libras no Brasil. Inicialmente, procede-se a uma breve revisão da literatura acerca dos empréstimos, em português e em Libras. Em seguida, apresenta-se, com base em entrevista feita com uma instrutora surda, descrição e análise de informaçōes fornecidas pela colaboradora, visando a dar visibilidade a aspectos da ampliação/ renovação lexical da Libras por meio de empréstimos feitos do português. A entrevista realizada foi semidirigida, ou seja, seguiu a utilização de um roteiro previamente elaborado. Com os dados recolhidos e analisados, pretende-se contribuir com as reflexões sobre os processos de formação de sinais em Libras. PALAVRAS-CHAVE: línguas em contato, empréstimos linguísticos, formação de sinais, Libras.

ABSTRACT: This article discusses situations of contact between Portuguese (aural-oral language) and Brazilian Sign Language - Libras (visual-spatial language), seeking to investigate the source loanwords deriving from social

\footnotetext{
*isabel060813@gmail.com

**angelabaalbaki@hotmail.com
} 
practices in which Libras users interact in Brazil. This study first presents a brief literature review on the loanwords in both Portuguese and Libras. Next, based on an interview conducted with a deaf instructor, a description and analysis of information provided by the collaborator is presented, which is designed to describe aspects of the expansion/renovation of the Libras lexicon by adopting loanwords from Portuguese. The interview was semistructured, i.e., it followed the use of a previously prepared script. Using the collected and analyzed data, we intend to contribute to the reflection on the processes of the formation of signs in Libras.

KEYWORDS: language contact, loanwords, sign formation processes, Brazilian Sign Language - Libras.

\section{Introdução}

Um aspecto fundamental de qualquer língua é a possibilidade que tem, por diferentes recursos, de ampliar e renovar seu léxico. Sandmann (1997, p.22-24), ao tratar desse tema, destaca três recursos de que se serve uma língua para ampliar seu vocabulário: um principal - a formação de palavras a partir de palavras/morfemas preexistentes - e dois secundários - os empréstimos de outras línguas e a "criação por assim dizer do nada" -, os três atendendo a funções sociais e linguísticas. Assim como Sandmann, outros autores também caracterizam recursos de formação de novas palavras, com pequenas diferenças de enfoque. Carvalho (2000), por exemplo, distingue entre "formações vernáculas" e "formaçōes por empréstimos".

Dentre os recursos comumente assinalados, chamam-nos a atenção os empréstimos ${ }^{1}$, que não devem ser desconhecidos de qualquer comunidade linguística, já que se relacionam a algum tipo de contato entre usuários de línguas diferentes. Em geral, trata-se de contato entre povos por proximidade geográfica, intercâmbio cultural ou por algum tipo de dominação, seja econômica, ideológica ou de outra ordem. Trataremos dos empréstimos basicamente como um processo de assimilação de material linguístico de uma língua por outra.

Essa possibilidade de ampliação/renovação lexical também está presente nas chamadas línguas de sinais, usadas pelas comunidades surdas de todo o mundo. No caso do Brasil, estudiosos da língua brasileira de sinais,

\footnotetext{
${ }^{1}$ Não consideramos, no presente artigo, a diversidade terminológica sobre o termo empréstimo. Para uma análise mais ampla a respeito de tal diversidade, confira Correia e Lemos (2005).
} 
doravante Libras (FERREIRA-BRITO, 1998, 2010; FELIPE, 1998, 2006; QUADROS e KARNOPP, 2004), vêm dando maior atenção à descrição de processos de formação de palavras com recursos da própria língua, com menos ênfase à questão do enriquecimento lexical por meio de empréstimos linguísticos. Pensamos com isso que, talvez, os empréstimos sejam, também para a Libras, um recurso secundário de ampliação do léxico, tal como caracteriza Sandmann (1997).

Surdos e ouvintes - brasileiros, por exemplo - compartilham traços culturais de sua nacionalidade comum, além, claro, de outros traços culturais. ${ }^{2} \mathrm{O}$ fato preponderante que gostaríamos de destacar é que, embora configurem comunidades linguísticas distintas, estão em permanente contato. ${ }^{3}$ Assim, é provável que haja influência de uma língua sobre a outra. Libras e português, contudo, são línguas de diferentes modalidades, cujos respectivos sistemas linguísticos apresentam formas peculiares de apreensão da realidade. Além disso, a comunidade surda compóe um segmento de minoria linguística que faz uso de uma língua ágrafa, em que pesem esforços de desenvolvimento de um sistema gráfico. No processo de escolarização, os surdos aprendem a modalidade escrita do português, e a Libras não é componente curricular obrigatório ${ }^{4}$ da educação básica. Esse conjunto de fatores aponta para a possibilidade de uma ampla influência do português sobre a Libras.

Tendo em vista, portanto, o papel fundamental que tanto Libras quanto português desempenham nas práticas sociais nas quais se insere o surdo brasileiro, parece-nos relevante considerar a produtividade que pode ter o recurso dos empréstimos tomados ao português nos processos de ampliação/renovação lexical da Libras.

Com o intuito de propor uma reflexão sobre esse tópico, entrevistamos uma surda, instrutora de Libras, ${ }^{5}$ a fim de avaliar os seguintes aspectos acerca

\footnotetext{
${ }^{2}$ Sugerimos que se consulte a discussão levantada por Strobel (2009) a respeito de comunidade e cultura surda.

${ }^{3}$ Segundo Carvalho (2009), os empréstimos de línguas em contato se dariam por relação interpessoal (entre os falantes dessas línguas) e por canais artificiais (no caso de distância). Na seção 5 deste artigo, verificamos que esses dois aspectos podem originar empréstimos na Libras.

${ }^{4}$ A Libras se tornou componente curricular obrigatório nos cursos de formação de professores por força do Decreto Federal no 5626/2005.

${ }^{5}$ Profissional, preferencialmente surdo, que possibilita a mediação da aprendizagem da e sobre a Libras. A formação desse profissional é prevista no Decreto Federal no 5626/2005.
} 
dos possíveis empréstimos feitos ao português: é possível reconhecê-los como um recurso produtivo entre os processos de ampliação/renovação lexical? Eles atendem a alguma função específica? Eles sofrem algum tipo de adaptação ou possuem relação com processos de formação a partir de morfemas preexistentes? Para proceder à análise dos dados da entrevista, tomaremos por base, principalmente, as formulaçōes teóricas de Sandmann (1997), sobre empréstimos em geral, e de Ferreira-Brito (1998, 2010), de Felipe (1998, 2006), de Quadros e Karnopp (2004), de Faria-Nascimento (2009) e de Nascimento (2010) sobre Libras. ${ }^{6}$

Destacamos que este trabalho não consiste em um estudo de corpus, em que ocorrências de empréstimos do português à Libras seriam sistematizadas por algum critério teórico-metodológico. Nosso objetivo é contribuir para a visibilidade de um tema de interesse ao campo das pesquisas sobre línguas em contato, procedendo a uma revisão de literatura e dando a palavra a um profissional surdo do ensino de Libras. As considerações desse profissional, articuladas às que fazemos, devem ser consideradas em uma perspectiva de problematização do tema, e não de descrição linguística.

\section{O lugar do léxico}

De modo genérico, podem-se reconhecer dois elementos constitutivos de uma língua: o primeiro é a gramática, entendida como as regras gerais que particularizam cada língua, e o segundo é o léxico. Mas o que caracteriza mais propriamente o léxico? Em Mattoso Câmara Jr. (1984, p.157), encontra-se a seguinte definição:

LÉXICO - Como sinônimo de vocabulário, o conjunto de vocábulos de que dispõe uma língua dada. Em sentido especializado, a parte do vocabulário correspondente às palavras, ou vocábulos providos de semantema, ou vocábulo que é lexema. Neste segundo sentido, o léxico se opõe à gramática, porque é a série dos semantemas da língua, vistos através da sua integração em palavras. As palavras se distribuem no léxico: 1) por Campos Semânticos (...); 2) por famílias léxicas (...). Num e noutro caso, têm-se sistemas em que as palavras se apresentam em

\footnotetext{
${ }^{6}$ Gostaríamos de agradecer à instrutora surda Adriana Veiga, cujas informaçōes fornecidas durante a entrevista possibilitaram a realização deste artigo. Gostaríamos de destacar também o trabalho da intérprete Mônica Raquel de Souza Lopez, que procedeu à revisão técnica das referências aos sinais e de suas transcriçôes.
} 
correlação e oposição; mas, ao contrário dos sistemas gramaticais, que consistem em grupos fechados de elementos, são sistemas abertos com um número de elementos indefinido. Por isto, é no léxico que se verifica a mudança por empréstimo. (...)

Em Rosa (2000) e em Basílio (2004) também se encontram definições que ecoam a noção do léxico como um conjunto dinâmico e em expansão:

O léxico representa o conjunto de palavras que está disponível para a atuação das regras da morfologia. (...) As palavras do léxico - ou lexemas ou, uma vez que pensamos numa lista, os itens lexicais - pertencentes a classes abertas, isto é, a classes que, sincronicamente, podem admitir novos membros e apresentam significado lexical. (ROSA, 2000, p.88).

O léxico (...) não é apenas um conjunto de palavras. Como sistema dinâmico, apresenta estruturas a serem utilizadas em sua expansão. Essas estruturas, os processos de formação de palavras, permitem a formação de novas unidades no léxico como um todo e também a aquisição de palavras novas por parte de cada falante. (BASÍLIO, 2004, p.10).

Pode-se dizer, assim, que as palavras constituem o léxico de uma língua. Há, porém, focos diversos de análise, que costumam conferir diferentes definiçôes para os termos "léxico", "vocabulário", "palavra". Vários teóricos (AZUAGA, 1996; ROSA, 2000; BASÍlLIO, 2004) discutem a complexa natureza dos "entes" que denominamos "palavras" e identificam possibilidades de emprego deste termo: palavra gráfica; palavra fonológica; formas de palavra; lexema; palavra morfossintática. Em que pese a importância de considerar essas possibilidades, gostaríamos de destacar, aqui, apenas a distinção básica entre léxico e gramática, além da referência feita por Mattoso ao léxico como "um sistema aberto com um número de elementos indefinido". Interessa-nos, em especial, o fato de as palavras integrarem a parte da língua que está, mais visivelmente, em constante processo de mudança, seja pelo aparecimento de novas palavras ou de novos significados para antigas palavras.

Essas considerações, portanto, chamam atenção para os recursos de ampliação/renovação lexical de que as línguas dispõem. Imbricadas com as práticas sociais que as criaram, as palavras compõem um sistema dinâmico, submetido a alterações ao longo do tempo. Essas alterações podem-se dar em maior ou menor grau, dependendo, segundo Carvalho (2000, p.192), 
de fatores sociolinguísticos e estruturais. Em relação aos primeiros, uma língua pode ser mais ou menos inovadora em consequência de servir a uma comunidade em expansão ou em retração, dominada ou dominadora. $\mathrm{O}$ aparecimento de novos signos reflete traços importantes do grupo social onde eles surgem. Em relação aos segundos, devem ser observadas as possibilidades de inovação previstas pela própria gramática da língua, por sua morfologia e até por sua fonética. Considerando esses aspectos gramaticais, verifica-se que há processos de renovação lexical mais e menos produtivos.

\section{O recurso dos empréstimos linguísticos}

Nas últimas décadas, a questão dos empréstimos linguísticos teve lugar de destaque na mídia brasileira, em especial em virtude da tomada de posição contrária, de alguns segmentos da população, ao que se chama de invasão indiscriminada de palavras estrangeiras. Um exemplo dessa reação foi o Projeto de Lei no 1676/1999, de autoria do então deputado federal Aldo Rebelo, que visava à defesa da língua pátria. ${ }^{7}$ Os empréstimos, contudo, não são um fenômeno particular de nossa época, nem de nosso país. Mas também não se estranha um levante de críticas a esse tipo de recurso de renovação lexical, que pode ser encarado como uma espécie de ameaça à soberania dos povos.

Mattoso Câmara Jr. (1985) explica que os empréstimos se relacionam com a história externa de contato de uma dada língua com a língua de outros povos. Ele cita Bloomfield (apud MATTOSO CÂMARA, 1985, p.196, 198), que divide os empréstimos em "íntimos" e "culturais". Os primeiros decorrem "do contato íntimo, num mesmo território, de populaçôes com línguas distintas" e podem ser de três conceitos, a saber: a) substrato, quando uma população conquistada adquire a língua dos dominadores; b) superstrato, quando os dominadores adotam a língua dos vencidos; c) adstrato, quando duas línguas coexistem no mesmo espaço territorial, influenciando-se mutuamente, podendo ou não criar um ambiente de bilinguismo.

Os empréstimos culturais são "provenientes de contatos a maior ou menor distância, sempre na base de um intercâmbio cultural". Mas longe de ser um procedimento amistoso, como a expressão "intercâmbio cultural"

\footnotetext{
${ }^{7}$ Para uma reflexão mais apurada sobre essa polêmica, sugere-se a leitura de Faraco (2001).
} 
talvez sugira, empréstimos culturais ocorrem, em geral, devido a fortes pressões ideológicas e econômicas. Segundo Carvalho,

ninguém pode negar que nenhum país, nenhuma civilização é estanque. Nós nos influenciamos, mutuamente, sendo que, quanto mais poderosa for uma nação, maior será a influência de sua língua e seu prestígio. Os atuais empréstimos do inglês [ao português] resultam de uma adaptação à concepção da sociedade e modo de vida americanos que penetram entre nós pelo cinema, pela imprensa, literatura e turismo, enfim, pela pressão econômica e cultural do imperialismo desta poderosa nação como também pelo processo de globalização a que se submetem os povos. São produtos de um mimetismo que se desenvolveu em razão do prestígio exercido pela sociedade de consumo, dominada pelo poder do dinheiro, sobretudo pelo dólar. (CARVALHO, 2000, p.196)

Mas, retomando a ideia de "intercâmbio cultural", parece-nos que também os "empréstimos íntimos" podem decorrer de certo intercâmbio, pelo reconhecimento de aspectos culturais diferenciados retratados em outra língua. Tomam-se emprestados termos cujos referentes ${ }^{8}$ ainda não estão nomeados ou que, até então, não faziam parte da língua que realiza o empréstimo. $\mathrm{Ou}$, ainda, tomam-se emprestados termos que até possuem equivalentes na língua que faz o empréstimo, mas que adquirem outra força expressiva, atendendo a particularidades de uso de usuários ou de grupos específicos de usuários. ${ }^{9}$ Enfim, consideramos que a distinção entre os empréstimos íntimos e os culturais advém, sobretudo, do tipo de contato geográfico entre as línguas envolvidas.

É importante destacar que os empréstimos representam uma forma de renovação lexical. Trata-se de uma palavra nova não por criação propriamente dita, mas por adoção. O empréstimo poderá sofrer ou não adaptações

\footnotetext{
${ }^{8}$ O termo "referente" está sendo empregado na concepção de Ogden e Richards (apud Rocha, 1999, p.98) de "objetos da realidade, as coisas, enfim, o mundo extralinguístico". ${ }^{9}$ Em Vilela (1994), encontramos referência a "empréstimos necessários" e "empréstimos de luxo": os primeiros atenderiam a uma necessidade "real" de palavras novas; e os segundos apenas importariam palavras que possuem equivalentes na língua que faz o empréstimo. $\mathrm{O}$ autor não tece maiores comentários, mas nos parece que não se atentou para os novos valores semânticos e expressivos do empréstimo. Um exemplo de empréstimo de luxo apresentado é "líder", que teria como equivalente "chefe". No entanto, sabemos que líder e chefe não possuem o mesmo sentido, nem o mesmo valor expressivo, em português.
} 
materiais, semânticas e expressivas em sua passagem para outra língua. Porém, em um primeiro momento, o que existe é adoção apenas. Segundo Carvalho, a adoção compreende várias etapas:

na sua primeira fase de aceitação, [o empréstimo] é definido como peregrinismo. Só será considerado empréstimo, numa fase ulterior, quando adotado verdadeiramente pela integração na morfologia da língua e pela generalização no seu uso corrente pelos falantes: passa então a não ser mais notado como um termo estrangeiro. (CARVALHO, 2000, p.196-197)

Porém, se muitos são os casos de termos estrangeiros que, com o tempo, deixam de ser notados como tal, integrando-se à língua que os adotou, há também casos de empréstimos que não perdem sua transparência aloglota. A classificação proposta por Sandmann (1997, p.23) para os empréstimos leva em consideração o tipo de transformações ocorridas na passagem de uma língua para outra. ${ }^{10}$ Descrevemos a seguir a proposta do autor, que nos parece a mais completa, organizando-a em dois casos.

Caso 1

- Empréstimos adaptados (líder, do inglês leader);

- Empréstimos não adaptados: ortograficamente (show), fonológica e ortograficamente (joint venture) e morfossintaticamente (campi, plural de campus).

\section{Caso 2}

- Empréstimos lexicais - sem tradução/substituição de morfemas/ palavras (esputinique, videoteipe, pulôver);

- Empréstimos semânticos - com tradução/substituição de morfemas/ palavras: com alteração de estrutura (spaceship $=>$ nave espacial) e sem alteração de estrutura (spaceship => espaçonave);

- Empréstimos estruturais - formados com recursos do português, mas segundo modelo estrutural estrangeiro (cineclube).

\footnotetext{
${ }^{10}$ Note-se que Sandmann está considerando como língua que faz o empréstimo o português.
} 
Como já assinalamos, os empréstimos podem atender a necessidades culturais, científicas e da comunicação de um modo geral. Basílio (1987) identifica algumas funções no processo de formação de novas palavras. Essa autora não menciona os empréstimos, mas as funções definidas constituem um parâmetro de reflexão também para as palavras adotadas de outras línguas. Segundo Basílio (1987) - e também em Sandmann (1997), que se baseia nessa autora -, a formação de novas palavras relaciona-se com funções linguísticas específicas. Segundo ela, tais funções são a de denominação e a de adequação ao enunciado. Em relação ao enunciado, esclarece:

O enunciado, por sua vez, pode ser encarado pelo menos de dois pontos de vista: de um ponto de vista mais global, no qual poderíamos incluir vários aspectos, desde a atitude do falante frente ao que está falando ou à situação de fala (discurso formal ou informal, distanciamento ou não, atitudes subjetivas, etc.) até a consideração da estrutura global do enunciado com seus diferentes pontos de conexão; e de um ponto de vista mais pormenorizado, focalizando as unidades menores que se interconectam na formação do discurso e que, em sua estruturação interna, se incluem no objeto de estudo da sintaxe. (BASÍLIO, 1987, p.67)

Basílio (1987) propõe que se desdobrem essas duas funções em três outras fundamentais para a formação de novas palavras, sempre com a possibilidade de elas se mesclarem:

- função semântica ou de denominação - visa à nomeação de coisas ou seres, novos objetos, fatos culturais novos, fenômenos da natureza que nos cerca ou da nossa realidade interior;

- função sintática ou de adequação sintática - está presente nos processos que operam mudança de classe de palavra;

- função discursiva ou de adequação discursiva-relaciona-se com processos que visam tanto a expressar aspectos subjetivos do emissor em relação ao conteúdo do que é comunicado quanto a operar uma adequação da estrutura do texto como um todo.

Ressaltamos, portanto, o fato de que a renovação do léxico - seja por formação de palavras ou por empréstimos, como desejamos enfatizar - vem ao encontro das necessidades de uso dos falantes de uma língua, não importando se essas necessidades são de ordem objetiva ou subjetiva. Como acrescenta Carvalho (2009), em relação aos empréstimos, "a adoção do termo estrangeiro pode ser um fato de cultura e gosto, mas é sempre gerada por uma necessidade prática. A cunhagem de um novo termo demanda tempo e interesse, enquanto a adoção é instantânea" (CARVALHO, 2009, p.80). 


\section{A morfologia da Libras}

As línguas de sinais, utilizadas pelas comunidades surdas de diversos países, têm merecido a atenção de pesquisadores de diferentes campos, destacando-se os linguistas. Embora já existam estudos sobre os aspectos morfológicos da Libras, ainda há muitas lacunas a serem preenchidas. A respeito desse aspecto incipiente da descrição linguística da Libras, Quadros e Karnopp (2004) asseveram que

A primeira dificuldade ao se tentar descrever e explicar a morfologia da língua de sinais brasileira é o peso da tradição, que dificulta a revisão e a adoção de novas posiçōes. A questão é: realizar um estudo da morfologia a partir da análise da morfologia das línguas orais ou reduzir-se ao estudo da morfologia das línguas de sinais? Ao optar-se pela primeira, podese desconsiderar as especificidades das línguas de sinais, quanto à sua modalidade de percepção e produção. Ao optar-se pela segunda, deparase com uma bibliografia reduzida e limitada, principalmente ao estudo da língua de sinais americana. Além disso, na língua de sinais brasileira, raros são os estudos linguísticos realizados nesta área (QUADROS e KARNOPP, 2004, p.84).

Essa constatação das autoras aponta para um campo de investigação que pode ser considerado recente, que é o da descrição das línguas de sinais. Somente em 1960, com a publicação de Sign language structure, do linguista norte-americano William C. Stokoe, é que as línguas de sinais começam a ser observadas como línguas. ${ }^{11}$ Stokoe procurou demonstrar que as línguas de sinais possuem "tanto um léxico de sinais que denotam os mesmos tipos de relações, ações e coisas que as palavras, como um sistema de quiremas, uma coleção de traços contrastantes, relativamente sem sentido e visivelmente distinguíveis que se combinam para compor os morfemas desse léxico" (STOKOE, 1972, p. 118, apud GLASS, 1996, p.20). Foi Stokoe quem primeiro definiu a língua americana de sinais (American Sign Language - ASL) como "composição simultânea de um conjunto limitado de configurações de mão, localizaçôes e movimentos" (KLIMA e BELLUGI, 1980, p.12, apud GLASS, 1996, p.20). A forte motivação icônica ${ }^{12}$ na criação

\footnotetext{
${ }^{11}$ Ressalte-se que os estudos de Stokoe referiram-se à American Sign Language. Contudo, as bases de sua pesquisa se refletiram em vários países, inclusive no Brasil.

${ }^{12}$ As reflexôes sobre as línguas de sinais costumam apontar para essa forte presença de sinais icônicos. A iconicidade, no entanto, é apenas uma motivação, já que o traço
} 
de vários sinais e a simultaneidade na articulação destes (em contraste com a linearidade da produção nas línguas orais-auditivas) são duas características determinantes que foram identificadas nas línguas de sinais.

Detendo-nos especificamente nos estudos brasileiros sobre língua de sinais, destacamos os trabalhos de Ferreira-Brito (1998, 2010), Felipe (1998, 2006), Quadros e Karnopp (2004), Faria-Nascimento (2009) e Nascimento (2010), que procuram descrever a Libras, enfatizando que esta, apesar de se atualizar em modalidade espaço-visual, possui gramática própria, a exemplo das línguas de modalidade oral-auditiva, constituída por itens lexicais e por mecanismos fonológicos, morfológicos, sintáticos, semânticos e pragmáticos que possibilitam a geração de estruturas linguísticas de forma produtiva.

As palavras ou itens lexicais são os sinais. De maneira geral, a estruturação das palavras das línguas orais (o português, por exemplo) pode ser analisada por suas unidades sonoras mínimas contrastivas - os fonemas - e por suas unidades de significado - os morfemas. Os sinais da Libras também se formam pela combinação de unidades mínimas denominadas parâmetros, que formam unidades mais complexas. Felipe (1998, p.84) define cinco parâmetros da Libras, que podem ser comparados aos fonemas e, às vezes, aos morfemas. São eles:

- configuração das mãos (CM) - basicamente, "forma" que a(s) mão(s) toma $(m)$ na articulação de um sinal, tendo Ferreira-Brito (1998, p.33) identificado $46 \mathrm{CM}$ na Libras;

- ponto de articulação (PA) - local onde incide a mão configurada do sinalizador;

- movimento $(\mathrm{M})$ - tipo de movimento ou de frequência com que o sinal pode ser realizado;

- orientação $(\mathrm{O})$ - direção em que o sinal é realizado;

- marcadores não manuais (MNM) - além da composição com os quatro parâmetros mencionados, o sinal também pode ser acompanhado de alguma expressão facial ou corporal.

icônico escolhido é de natureza convencional. Por que representar "mãe" e "pai”, por exemplo, fazendo o gesto de quem "toma a bênção"? Qualquer outro traço poderia ter sido privilegiado. $\mathrm{O}$ fato é que, no decorrer do tempo, as propriedades icônicas muitas vezes se tornam opacas, e os signos, sincronicamente, são percebidos como puramente arbitrários. 
De acordo com Felipe (2006), esses cinco parâmetros

podem expressar morfemas através de algumas configurações de mão, de alguns movimentos direcionados, de algumas alteraçōes na frequência do movimento, de alguns pontos de articulação na estrutura morfológica e de alguma expressão facial ou movimento de cabeça concomitante ao sinal, que, através de alterações em suas combinaçōes, formam os itens lexicais das línguas de sinais. São, portanto, (...) morfemas lexicais ou gramaticais que podem ser, diferentemente, uma raiz/radical $(\mathrm{M})$, um afixo (alterações em M e CM) e uma desinência, ou seja, uma marca de concordância número-pessoal (O) ou de gênero (CM). (FELIPE, 2006, p.202)

O sinal é formado, portanto, pela combinação desses parâmetros. Felipe (2006) diz que os processos de formação de palavras na Libras podem ocorrer por meio de modificações por adição à raiz, de modificação interna da raiz, de processos de derivação zero, de processos de composição e de processos miméticos. Nos artigos que citamos da autora, não se faz referência a empréstimos linguísticos, nem se enfatiza o tema renovação lexical, foco deste trabalho.

\section{Os empréstimos linguísticos na Libras}

Conforme já mencionado, os trabalhos sobre morfologia em Libras apresentam caráter predominantemente descritivo no que diz respeito aos processos de formação de palavras, com pouco foco na reflexão sobre as possibilidades de renovação lexical. Lembramos também que, ainda que nosso artigo aborde as situações de empréstimos, avaliamos que os processos de formação a partir dos recursos da própria língua devam ser os mecanismos principais de ampliação do léxico em Libras, assim como o são em português (cf. Sandmann, 1997). Apenas um estudo de outra ordem poderia apresentar dados mais concretos acerca dessa produtividade.

Sabe-se que, considerando a situação sociolinguística das comunidades surdas ${ }^{13}$ em geral, e da brasileira em particular, trata-se de um grupo de minoria linguística, ${ }^{14}$ com a peculiaridade de fazer uso de uma língua de

\footnotetext{
${ }^{13}$ Quando falamos em comunidade surda, estamos pressupondo o uso da língua de sinais como primeira língua pelos integrantes dessa comunidade.

${ }^{14}$ Cavalcanti (1999) identifica cinco contextos bi/multilíngues de minoria no cenário sociolinguístico brasileiro: comunidades indígenas, de imigrantes, de fronteira, de surdos e dialetais/rurbanas.
} 
modalidade diferente. Essa convivência de duas línguas em um mesmo espaço geográfico propicia condições de intercâmbio linguístico. Valendonos da denominaçãoo anteriormente apresentada de Bloomfield, diríamos que há um ambiente possível para a ocorrência de empréstimos íntimos. Assim, tendo em vista o papel fundamental que tanto Libras quanto português desempenham nesse ambiente (com ênfase no fato de que, no processo de escolarização, o português é aprendido na modalidade escrita pelo surdo), acreditamos que o estudo dos empréstimos do português à Libras mereça destaque. ${ }^{15}$

Voltando-nos agora para a questão específica do contato entre Libras e português, a delimitação dos parâmetros e dos processos de formação que citamos vai de encontro ao pensamento habitual de que os sinais em Libras seriam a simples soletração manual (o uso do chamado alfabeto datilológico) de palavras em português. Acreditamos que esta concepção se baseie não somente no desconhecimento das línguas de sinais, mas também no fato de os surdos usuários da Libras (assim como os de outras línguas de sinais) precisarem fazer uso, em diversas situações, da língua usada pelos ouvintes com os quais aqueles convivem. Assim, um primeiro fato a se observar é que a datilologia ou soletração manual, amplamente conhecida pelos que falam Libras, tem relação com os empréstimos, conforme corrobora Ferreira-Brito (1998):

Então, o léxico da Libras, assim como o léxico de qualquer língua, é infinito no sentido de que sempre comporta a geração de novas palavras. (...) Por exemplo, a Libras não tinha um sinal para o conceito "linguística" até há poucos anos. À medida que os surdos foram se inteirando do que se faz em linguística, do que significa linguística, houve a necessidade de se gerar um sinal para esse conceito. O sinal LINGUÍSTICA não é a soletração da palavra em português, porém tem um vestígio de

\footnotetext{
${ }^{15}$ As línguas de sinais, em modalidade espaço-visual, constituem uma construção cultural dos surdos. No entanto, a surdez foi durante muito tempo avaliada como deficiência, e não como diferença. Isso fez com que as línguas de sinais fossem vistas com descrédito e proibidas, sendo impostas aos surdos as línguas orais-auditivas. Dadas as dificuldades óbvias com essa modalidade de expressão e a proibição da língua de sinais, os surdos têm sido excluídos do acesso a uma série de bens culturais e de práticas sociais partilhados pelo uso de uma língua. Acreditamos que a interdição às línguas de sinais tenha resultado em grande prejuízo não só ao fortalecimento das comunidades surdas, mas também à ampliação do léxico dessas línguas.
} 
empréstimo porque a configuração de mão escolhida é L (apenas os dedos polegar e indicador estendidos), uma configuração própria da Libras que costuma representar a letra "L" no alfabeto manual. Este sinal é realizado com as duas mãos, palmas para baixo com o polegar de uma mão quase tocando o da outra, na frente do busto, fazendo os movimentos de rotação positiva e de translação retilínea para os lados. (FERREIRA-BRITO, 1998, p.30. $)^{16}$

Quadros e Karnopp (2004) iniciam sua reflexão a respeito do léxico da Libras a partir da distinção entre sinais nativos e sinais não nativos. Os primeiros estariam representados no núcleo do conjunto do léxico e os últimos, na periferia. Neste subconjunto dos itens lexicais não nativos estariam contidas as palavras de língua portuguesa que são digitadas/ soletradas manualmente. Segundo as autoras, a "soletração manual não é uma representação direta do português, é uma representação manual da ortografia do português, envolvendo uma sequência de configurações de mão que tem correspondência com a sequência de letras escritas do português" (QUADROS e KARNOPP, 2004, p.88).

As autoras focalizam os empréstimos da Libras em relação à língua portuguesa no extremo da periferia, uma vez que tais itens lexicais se conformariam "minimamente às restriçôes da língua" (QUADROS e KARNOPP, 2004, p.90). Isso ocorreria porque os empréstimos, por meio de soletração manual, violariam as restriçōes na mudança de configuração de mãos $(\mathrm{CM})$. As mudanças nesses sinais-empréstimos adviriam, através dos tempos, por uma acomodação desses itens às restrições de boa formação das regras sistêmicas de cada língua de sinais, em outros termos, os empréstimos passariam por ajustamentos referentes às restrições fonológicas de cada língua de sinais. O exemplo trazido pelas autoras é da palavra "nunca" que passou da soletração manual N-U-N-C-A ${ }^{17}$ para a forma N-U-N-U com um grau

\footnotetext{
${ }^{16}$ Atualmente, o sinal que identifica o referente "linguística" se produz da seguinte forma: as duas mãos em $\mathrm{CM}$ em $\mathrm{L}$, com dedos indicadores próximos um ao outro e apontados para o queixo, afastar indicadores com movimento de abertura para frente e para os lados fechando em $S$.

17 Por uma questão de espaço, não inserimos no presente artigo fotos ou imagens dos sinais. Usamos o sistema de transcrição de sinais usado por Quadros e Karnopp (2004). Trata-se de um sistema que emprega palavras da língua portuguesa em letras maiúsculas para indicar os sinais; hífen para indicar quando mais de uma palavra do português é usada para descrever um único sinal; ^ ${ }^{\wedge}$ para indicar sinais compostos;
} 
maior de nativização. Essa seria, portanto, a forma diferenciada do modo de organização dos empréstimos linguísticos no léxico das línguas de sinais em relação às línguas orais: o item entra na língua por meio de um sistema de representação ortográfica. Para as autoras,

as formas soletradas manualmente não são completamente independentes dos sinais nativos da língua de sinais brasileira; antes, as restrições formacionais propostas para sinais nativos aplicam-se também, em vários graus, às formas soletradas manualmente e ao léxico não nativo (QUADROS e KARNOPP, 2004, p.92).

Embora comentem a questão dos empréstimos linguísticos, as duas autoras não os tomam explicitamente como um mecanismo de expansão lexical, tratando-os como léxico não nativo e colocando-os na periferia do conjunto do léxico da língua de sinais. $\mathrm{O}$ foco de suas análises parece recair, assim, sobre os aspectos formativos dos itens lexicais, enquanto aqui gostaríamos de dar mais visibilidade ao tema da expansão do léxico por meio dos empréstimos, explorando um pouco mais o contato entre Libras e português.

Nascimento (2010), ao dedicar seu estudo aos empréstimos linguísticos de Libras, distancia-se relativamente das autoras anteriormente citadas. Segundo ela, a aceitação dos empréstimos linguísticos originários de outras línguas pode estar relacionada a vários aspectos da comunidade linguística receptora. Logo, haveria tanto movimentos de adoção/incorporação dos empréstimos quanto de resistência a eles. Sua principal função seria preencher lacunas lexicais de uma língua de forma a ampliá-la.

Para a autora, em geral, quando se trata de empréstimos em língua de sinais, destacam-se de imediato aqueles adotados a partir de línguas orais-auditivas, sem dúvida pelo contato intenso que se mantém com elas. A especificidade deste empréstimo, como já visto antes, reside na adaptação da escrita (sistema ortográfico) da língua de modalidade-oral auditiva para a datilologia em língua de sinais. Os empréstimos realizados por meio da datilologia, com o uso, acabam sendo adaptados às características fonológicas (quirêmicas) das línguas de sinais, produzindo, em muitos casos, o apagamento de sua origem externa, não nativa.

@ para mostrar a ausência da marca morfológica de flexão de gênero na Libras. Por fim, destacamos que no caso do uso da datilologia a transcrição de palavras deve ser apresentada separada por hífen, como em N-U-N-C-A. 
Nascimento (2010) ainda cita os empréstimos originários do contato entre línguas de sinais, especialmente em razão de congressos e eventos internacionais. Um exemplo é a incorporação dos sinais que identificam os países, pelas diferentes comunidades surdas, tal como eles se apresentam na língua de sinais do país em questão. No Brasil, observa-se que o contato entre falantes de diferentes línguas de sinais, sobretudo em congressos pela inserção da Libras e de seus falantes em espaços acadêmicos, e o contato mediatizado, por meio do uso de novas tecnologias de informação, como chats e plataformas de compartilhamento de vídeos, vêm possibilitando empréstimos.

Por fim, Nascimento (2010) acrescenta ainda que há empréstimos menos recorrentes, que aparentam reproduzir a articulação dos lábios de certas palavras das línguas orais-auditivas, como as expressões interrogativas (COMO?, O-QUE?), que serviriam para desambiguizar termos semelhantes.

Ferreira-Brito (2010), em capítulo sobre aspectos gerais da estrutura linguística da Libras, dedica-se brevemente aos empréstimos, elencando cinco tipos de empréstimos aos quais os usuários de Libras recorreriam (lexical, inicialização, itens lexicais de outras línguas de sinais, domínio semântico, ordem fonética). Aqui, também, os empréstimos são apresentados sem serem relacionados com a expansão lexical.

Para a autora, os empréstimos lexicais são aqueles que ocorrem, em geral, por meio do uso da soletração manual. Tal recurso é recorrente na representação datilológica de nomes próprios e/ou de conceitos que ainda não tenham um sinal específico em Libras. A inicialização seria um tipo de empréstimo que tem como recurso o uso da primeira letra da palavra escrita em língua portuguesa. Um exemplo seria o sinal de BRASIL realizado com a mão direita em CM em B: palma para a esquerda, dedos para cima, altura do rosto, movimento de descida tremulante até altura do peito. A terceira tipologia são os empréstimos advindos de outras línguas de sinais. Podemos citar um sinal muito utilizado na comunidade surda brasileira: é um empréstimo da língua de sinais americana (ASL). Trata-se da declaração EUTE AMO: CM em L + dedo mínimo esticado. Nesta única configuração é possível identificar as iniciais das palavras contidas em I love you. Um outro tipo trazido por Ferreira-Brito (2010) é o do domínio semântico. Segundo a autora, por exemplo, os sinais para as cores são empréstimos, com exceção do amarelo - isso parece indicar que o domínio semântico das cores parece não ser relevante para os sinalizantes em Libras. Por fim, o último tipo é o 
de ordem fonética, que corresponde à reprodução da articulação do som de algumas palavras da língua portuguesa.

Destacamos, por fim, a contribuição de Faria-Nascimento (2009), que sistematizou uma tipologia mais ampla: empréstimo por transliteração (pragmática e lexicalizada), empréstimo por transliteração de letra inicial, empréstimo da configuração visual dos lábios, empréstimo semântico, empréstimo estereotipado e empréstimo cruzado.

Ao considerar a transliteração, a autora abrange tanto a definição corrente de datilologia ${ }^{18}$ (visto que essa deve ser realizada em espaço neutro, ou seja, aquele no qual as letras são soletradas manualmente na área em frente ao tronco, sem ponto de contato com o corpo) quanto as configuraçôes de mão $(\mathrm{CM})$ que são produzidas fora do espaço neutro. A transliteração é considerada a "representação de letras de uma língua oral por CM de uma língua de sinais" (FARIA-NASCIMENTO, 2009, p.61). Esse processo está subdividido em dois grupos: transliteração pragmática e lexicalizada.

Os empréstimos por transliteração pragmática correspondem ao uso da datilologia, de forma provisória, para um sinal inexistente em Libras (uma espécie de lacuna terminológica) ou de forma permanente para nomes completos de pessoas, de marcas, de topônimos, em contextos específicos (preenchimento de formulários, por exemplo). O empréstimo por transliteração lexicalizada tem caráter mais estável, visto que já estão adaptados às restrições fonomorfológicas da Libras. Em consequência, apresentam mudança rítmica em relação aos itens puramente datilológicos. A autora traz exemplos de palavras inteiras, como A-L-H-O, ou formas reduzidas, como N-U-N-U (forma lexicalizada para "nunca").

O segundo tipo - transliteração de letra inicial - caracteriza-se por um hibridismo: uma parte da formação do sinal corresponde ao empréstimo (CM corresponde a letra inicial da palavra escrita em português) e a outra parte segue as regras de formação de itens lexicais nativos da Libras. Veja-se, por exemplo, o sinal ÉTICA, formado pelas duas mãos em CM em E, em espaço neutro, na altura do peito, com as palmas para a frente, arrastando-se até a cintura.

O terceiro empréstimo, de configuração visual dos lábios, refere-se à imitação parcial ou total da articulação da palavra da língua portuguesa.

\footnotetext{
${ }^{18}$ Gostaríamos de destacar que, apesar deste enfoque da datilologia como forma de empréstimo, ela também pode atender a outros usos, como o de metacódigo na interação de professores de língua portuguesa e alunos surdos sinalizantes.
} 
A autora salienta que, em geral, a sílaba tônica é representada, servindo como uma pista visual produzida simultaneamente ao sinal equivalente em Libras. Um exemplo seria usar articulação oral da palavra em português, para diferenciar dois conceitos expressos por um mesmo sinal, como SONHO e IMAGINAÇÃO, como costuma ocorrer no Rio de Janeiro.

O quarto tipo, não facilmente identificável como empréstimo, é o semântico. Esse funciona como um decalque da carga semântica e cultural da palavra traduzida literalmente para Libras. É muito comum em expressões idiomáticas, como, por exemplo, "cair o queixo", em que o sinal em Libras foi criado para expressar o sentido literal já existente em português.

O empréstimo estereotipado corresponde à reprodução de símbolos gráficos convencionados em várias culturas, por exemplo, os sinais gráficos de pontuação (vírgula, ponto de interrogação, etc.). Tais símbolos são normalmente (re)produzidos no ar, a partir de um ponto fixado no espaço neutro, pelo dedo indicador da mão passiva.

O último tipo, empréstimo cruzado, ocorre com palavras graficamente semelhantes (ou até iguais) em língua portuguesa que, embora tenham referentes distintos, recebem o mesmo sinal em Libras, como o caso de BOLSA (sacola) e BOLSA (de estudos) e MESQUITA (cidade da baixada fluminense, RJ) e MOSQUITO (inseto).

É possível estabelecer entre Ferreira-Brito (2010) e Faria-Nascimento (2009) certa correspondência: empréstimos lexicais / empréstimos por transliteração; inicialização / empréstimos por transliteração de letra inicial; empréstimos de ordem fonética / empréstimos da configuração visual dos lábios. O destaque para a contribuição de Faria-Nascimento advém da proposta de inserção dos empréstimos no rol dos processos de expansão lexical da Libras. Na seção a seguir, apresentamos considerações sobre o tema com base na entrevista feita.

\section{Análise das informações fornecidas pela colaboradora surda}

O material de análise deste trabalho é composto de dados obtidos por meio de uma entrevista semidirigida, realizada com uma instrutora surda de Libras. A opção por entrevistar um instrutor surdo de Libras (fluente nessa língua) deve-se ao fato de esse profissional lidar especificamente com a língua objeto de análise deste trabalho. Como ensina a Libras a surdos e a ouvintes, o instrutor costuma se deter na reflexão sobre aspectos de natureza 
linguística, tanto da Libras quanto do português. $\mathrm{Na}$ época da entrevista, a colaboradora possuía o curso de formação de instrutores oferecido pela Federação Nacional para Educação e Integração dos Surdos (FENEIS) ${ }^{19}$ e trabalhava no município de Angra dos Reis (RJ) e também no Instituto Nacional de Educação de Surdos - INES (RJ).

Optou-se por fazer uma entrevista semidirigida, ou seja, de caráter não estruturado, mas focalizada. A principal característica desse instrumento metodológico são questionamentos básicos apoiados em aspectos que se relacionam ao tema da pesquisa. Partiu-se, assim, de um roteiro prévio de questôes, mas dando-se liberdade para a entrevistada e entrevistadoras de não o seguirem rigorosamente. Pediu-se, inclusive, à colaboradora que ficasse à vontade para realizar qualquer tipo de comentário ou pedir esclarecimento. O roteiro possuía quatro questóes:

1) Como se dá a ampliação do léxico na Libras?

2) São comuns empréstimos do português?

3) De que tipo? Esses empréstimos sofrem adaptaçōes na Libras? Você poderia citar exemplos?

4) Esses empréstimos atendem a funções específicas?

Seguiremos nesta análise o roteiro usado na entrevista, fazendo um relato sistematizado do depoimento da instrutora. Por relato sistematizado, queremos dizer que não foi feita a reprodução literal de tudo o que foi dito. Após várias leituras do material, retiramos as repetições, alguns pedidos de esclarecimento, comentários desvinculados da pesquisa, selecionando somente material que servisse aos objetivos pretendidos. Respeitaram-se na íntegra as informações dadas e a forma como foram dadas. Procederemos à análise dos dados à medida que formos apresentando o relato.

\section{Como se dá a ampliação do léxico na Libras?}

A entrevistada apresentou duas possibilidades, que relatamos a seguir.

É comum os jovens da comunidade surda, em especial os estudantes do INES, criarem uma nova forma de se dizer alguma coisa. Ninguém sabe direito

\footnotetext{
${ }^{19} \mathrm{O}$ primeiro curso de Letras-Libras começou a ser oferecido pela Universidade Federal de Santa Catarina em 2006. Antes, ficava unicamente a cargo da FENEIS a formação de instrutores. Também já foi bastante comum a presença de instrutores leigos em escolas e em cursos livres de Libras.
} 
quem cria o novo termo, ele apenas se propaga e sabe-se que partiu de alunos do INES. ${ }^{20}$ Deu como exemplo um novo sinal para NERVOS@. A entrevistada disse tratar-se de uma gíria. Os recursos utilizados na produção desse novo sinal são próprios da Libras. Destacamos o fato de citar "os alunos do INES", o que aponta para a possibilidade de a gíria, também entre usuários da Libras, ser característica de grupos determinados, em especial jovens.

Quando é preciso criar um sinal para algo novo, que os surdos ainda não conhecem, o grupo envolvido com esse "algo novo" pensa numa forma de sinalizá-lo. ${ }^{21}$ Deu como exemplo o sinal de BILINGUISMO, que fora um neologismo na década de 1990 . Os recursos utilizados na produção deste novo sinal eram próprios da Libras. Isso ocorre também com sinais criados por surdos envolvidos em campos de conhecimento específico, como os que cursam faculdade de contabilidade, informática, etc.

Notamos que, pelo menos nesse primeiro momento, a entrevistada identificou como forma de ampliação do léxico em Libras apenas processos que se valem unicamente de recursos da própria língua, como o emprego de morfemas preexistentes e a combinação dos parâmetros, como os citados por Felipe (1998).

\section{São comuns empréstimos do português?}

Neste item, foi preciso que explicássemos o que eram empréstimos linguísticos, como aconteciam, por que aconteciam, suas adaptações, seus usos. Demos vários exemplos de empréstimos de outras línguas presentes no português e, então, perguntamos se a colaboradora achava comum encontrar na Libras palavras emprestadas do português. Ela prontamente disse que sim.

De que tipo? Esses empréstimos sofrem adaptaçôes na Libras? Você poderia citar exemplos?

A entrevistada, neste momento, refletiu bastante, tentando identificar o que era ou não palavra emprestada do português. Foi anotando as palavras

\footnotetext{
${ }^{20} \mathrm{Na}$ referência aos alunos do INES, identificamos a questão política envolvida na legitimação de novos sinais criados. O INES começou a funcionar em 1856. É considerado um centro de referência na área da surdez, mantendo turmas de toda a educação básica, de graduação e de pós-graduação.

${ }^{21}$ Estamos usando os termos sinal, sinalizar, de acordo com os critérios de Felipe (1998) de constituição do léxico da Libras.
} 
de que se lembrava e que achava se tratar de empréstimos. Depois de listar algumas palavras, começamos a conversar sobre elas e a tentar classificá-las.

Antes de apresentar as palavras citadas pela colaboradora, é importante fazer alguns esclarecimentos. Conforme expusemos anteriormente, há, por parte de muitos que desconhecem a Libras (e as línguas de sinais como um todo), a sensação de que esta não passa da adaptação do alfabeto escrito para que este possa ser utilizado pelas mãos. De fato, na Libras, existe uma configuração de mão $(\mathrm{CM})$ para cada letra do alfabeto. Na revisão de literatura que fizemos, vimos que diferentes autores propóem uma abordagem para esta temática, alguns, inclusive, estabelecendo tipologias para os empréstimos. Optamos aqui por apresentar as informações da colaboradora sem vinculá-las a tais tipologias, seguindo a organização presente em seus comentários. Nessa organização, estabeleceram-se duas possibilidades de emprego das configurações de mão nos empréstimos:

A. Empréstimos com emprego de uma única $\mathrm{CM}$

A.1 CM não está articulada com outros parâmetros, representando simplesmente uma letra do alfabeto da língua oral, no caso, a língua portuguesa.

A.2 CM esta articulada com um ou mais parâmetros, formando um sinal.

B. Empréstimos com emprego de mais de uma CM

B.1 A sequência de letras da palavra em português é reproduzida linearmente no espaço tridimensional por meio das respectivas CM.

B.2 A sequência de letras da palavra em português não é necessariamente reproduzida na íntegra (podem-se “digitar”, por exemplo, apenas duas letras) e é acompanhada de um ou mais parâmetros. Neste caso, o conjunto é percebido como um sinal.

Esses casos constituiriam empréstimos feitos pela Libras ao português, pelo simples fato de que não há alfabeto em língua de sinais. ${ }^{22}$ Toda a noção de alfabeto e de sílaba é baseada em sonoridade, aspecto ausente nestas línguas. A criação das CM para as letras do alfabeto são consequência do íntimo convívio entre duas línguas de modalidades diferentes e, sobretudo, da necessidade dos surdos de fazerem uso das palavras em português por toda a situação social que eles vivenciam.

${ }^{22}$ Para aprofundar essa discussão, recomendamos Silva (2012). 
Dito isto, podemos agrupar as palavras emprestadas, citadas pela entrevistada, nos grupos A e B. O grupo A.1, de fato, não contém sinais. Cabe avaliar se tais casos constituem, em sentido estrito, alguma forma de empréstimo. O grupo B.1 pode conter quaisquer palavras do português, reproduzidas em datilologia, mas que não foram sentidas como empréstimos pela instrutora por não estarem integradas ao léxico da Libras. São usadas como uma espécie de alternância de código, nos casos em que o surdo (ou o intérprete) não reconhece nenhum sinal (mesmo em forma de empréstimo) que corresponda a um referente em Libras. Para que o surdo possa fazer uso do recurso descrito em B.1, é preciso que ele tenha bom nível de informação e de escolaridade, além de bom conhecimento de português. ${ }^{23}$ Neste grupo também se pode incluir a pura datilologia de nomes próprios, cabendo também a discussão se constituiriam empréstimos em sentido estrito.

Os itens A.2 e B. 2 constituiriam casos de empréstimos adaptados. Desconsiderando, então, os itens A.1 e B.1, podemos dizer o seguinte:

- O grupo de palavras citadas pela colaboradora que se incluem no item A.2 apresenta sinais que são motivados por empréstimo. É feita uma adaptação de modo que a formação do sinal combine apenas a configuração de mão correspondente à letra inicial da palavra emprestada do português com outros parâmetros. Exemplos: CÉU / BRASIL / ARGENTINA / PAÍS / MESTRADO / PEDAGOGIA / IMPORTANTE / RESPONSABILIDADE / CULTURA / VINHO / VIDRO / COPO / PRATO / SOLTEIRO / REGRA / RODOVIÁRIA / PROFESSOR / DEUS / FOFOCA / RESTAURANTE / SUPERMERCADO.

- O grupo de palavras citadas que se incluem no item B.2 sofre um tipo de adaptação bem diverso. Assim como existem as leis fonéticas agindo na adaptação de palavras em línguas como o português, o inglês, etc., parece haver algum tipo de coerção que faz com que se quebre a linearidade na representação tridimensional das palavras emprestadas, sendo acrescentado um ou mais parâmetros à digitação da palavra. Ou seja, as palavras deixam de ser apresentadas como se se estivesse escrevendo no espaço, uma letra

\footnotetext{
${ }^{23}$ Talvez seja possível considerar em B.1 empréstimos que estão incorporados ao léxico da Libras, mas que são digitados linearmente, sem perda de letras, configurando uma situação de empréstimos não adaptados.
} 
após a outra. E, nesse processo de perda da linearidade, podem-se perder também "letras". Exemplos: CUNHAD@ / JUNHO / JULHO / OI / MÃE / PAI / HOMOSSEXUAL / NUNCA / SOL / LEI / BANCO (instituição financeira) / FIM / PAZ / OU / É / APOSENTADO / BAR.

\section{Esses empréstimos atendem a funçōes especificas?}

A instrutora avaliou que os empréstimos servem, de maneira geral, justamente para ampliar e enriquecer o léxico, atendendo a uma necessidade da comunidade surda. Pedimos que ela tentasse ser mais especifica, explicando com mais detalhes o porquê da ocorrência dos empréstimos. Em alguns casos que nos chamaram a atenção, pedimos que desse um exemplo contextualizado de uso do empréstimo. Assim, nós mesmos fomos identificando as funções. Em consonância com a proposta de Basílio (1987), referente às funções das formações de novas palavras, a função principal, identificada na maior parte dos empréstimos, foi a de denominação. Identificamos a função de adequação sintática/discursiva no uso de É, e a função puramente discursiva no uso de FIM (no lugar de ACABAR, por exemplo). Ela citou o empréstimo de BANCO, considerado um uso de maior prestígio, que substituiu um sinal anterior.

\section{Considerações finais}

Este trabalho procurou refletir sobre a produtividade dos empréstimos do português à Libras como recurso de ampliação/renovação lexical. Mais do que pensarmos em questôes relacionadas à morfologia da língua, embora este seja um tópico de grande relevância, nosso interesse era verificar como falantes da Libras podem perceber e identificar o processo de empréstimos em relação ao português. Com isso destacamos que o nosso trabalho não teve como objetivo criar tipologias para empréstimos ou mesmo descrever tal fenômeno, mas suscitar questões acerca da sensibilidade de um falante de língua de sinais para considerar a adoção de termos oriundos de uma língua oral. Parece-nos possível dizer que se trata de um recurso relevante, cujos processos e usos merecem a atenção dos pesquisadores. A própria instrutora entrevistada que não conhecia esse fato de língua de forma sistematizada e que, de início, não mostrava um olhar aguçado para identificá-lo, rapidamente elencou uma série de empréstimos. 
Um relato seu nos chamou atenção e vem ao encontro dessa constatação da relevância desse recurso para a Libras. Ela contou que havia digitado (linearmente) a palavra "bar" para um amigo também surdo, e este não entendeu do que se tratava. Quando ela usou o empréstimo adaptado $\mathrm{BAR}$, um sinal da Libras, ele prontamente o reconheceu. $\mathrm{O}$ mais interessante neste caso é que no empréstimo BAR não há perda de letra; apenas as letras não são apresentadas linearmente, e sim num movimento "giratório". De acordo com a instrutora, o mesmo pode acontecer com outros empréstimos que deixam de ser percebidos como tal, mostrando sua perfeita integração à língua que toma o empréstimo.

Uma consideração final que gostaríamos de fazer diz respeito ao envolvimento da instrutora surda com a entrevista. Sentimos que ela ficou bastante surpresa - e até feliz - ao perceber os vários aspectos que envolvem esse tema. Achamos que essa reação se deveu, principalmente, ao fato de ela ter se dado conta da presença de recursos idênticos ao do português, do inglês, do francês, em sua língua. Avaliamos que a situação de discriminação ou de desprestígio de que a Libras foi vítima tenha concorrido para essa reação da entrevistada. Afinal, a Libras, como já apontamos, não integra o currículo escolar oficial, a não ser em nível superior nas licenciaturas. Esperamos que, o mais breve possível, esse contexto se modifique.

\section{Referências}

AZUAGA, Luísa. Morfologia. In: FARIA-NASCIMENTO I. H. (Org.). Introdução à linguística geral e portuguesa. Lisboa: Editorial Caminho S.A., 1996.

BASÍLIO, Margarida. Teoria lexical. 2.ed. São Paulo: Ática, 1987.

BASÍLIO, Margarida. O princípio da analogia na constituição do léxico: regras são clichês lexicais. Veredas: Revista de Estudos Linguísticos, Juiz de Fora, vol.1, n. 1, 1997. BASÍLIO, Margarida. Formação e classes de palavras no português do Brasil. São Paulo: Contexto, 2004.

MATTOSO CÂMARA JR., J. Dicionário de linguistica e gramática. 11.ed. Petrópolis: Vozes, 1984.

MATTOSO CÂMARA JR., J. História e estrutura da lingua portuguesa. 4.ed. Rio de Janeiro: Padrão, 1985.

CARVALHO, Nelly. Neologismos, informação e criatividade. In: AZEREDO, José C. de (Org.). Lingua portuguesa em debate: conhecimento e ensino. Petrópolis: Vozes, 2000. 
CARVALHO, Nelly. Empréstimos linguísticos na língua portuguesa. São Paulo: Cortez, 2009.

CAVALCANTI, Marilda. Estudos sobre educação bilíngue e escolarização em contextos de minorias linguísticas no Brasil. D.E.L.T.A. [online], São Paulo, vol.15, n.spe, p.385-417, 1999.

CORREIA, Margarita; LEMOS, Lúcia San Payo de. Inovação lexical em português. Lisboa: Edições Colibri, 2005.

FARACO, Carlos Alberto (Org.). Estrangeirismos: guerras em torno da língua. São Paulo: Parábola, 2001.

FARIA-NASCIMENTO, Sandra Patrícia de. Representações lexicais da LSB: uma proposta lexicográfica. 2009. Tese (Doutorado em Linguística). Brasília, Universidade de Brasília, Instituto de Letras, 2009.

FELIPE, Tanya A. Introdução à gramática da Libras. In: FERREIRA-BRITO, Lucinda et. al. (Org.). Programa de capacitação de recursos humanos do ensino fundamentallvol.III: Lingua Brasileira de Sinais. Brasília: MEC/SEESP, 1998. (Série Atualidades Pedagógicas).

FELIPE, Tanya A. Os processos de formação de palavra na Libras. ETD - Educação Temática Digital, Campinas, v.7, n.2, p.200-217, jun. 2006.

FERREIRA-BRITO, Lucinda. Língua Brasileira de Sinais - Libras. In: et al. (Org.). Programa de capacitação de recursos humanos do ensino fundamentallvol.III: Lingua Brasileira de Sinais. Brasília: MEC/SEESP, 1998. (Série Atualidades Pedagógicas).

FERREIRA-BRITO, Lucinda. Por uma gramática de língua de sinais. Rio de Janeiro: Tempo Brasileiro, 2010.

GARCEZ, Pedro M. Diversidade linguística: considerações para a tradução. In: Trabalhos de Linguistica Aplicada, jan./jun. Campinas: Ed. da Unicamp, 1999.

GLASS, Maria H. F. Por uma abordagem performativa das línguas de sinais. Dissertação (Mestrado em Linguística). Campinas, Unicamp, IEL, 1996.

NASCIMENTO, Cristiane Batista do. Empréstimos linguisticos do português na lingua de sinais brasileira LSB: línguas em contato. 2010. Dissertação (Mestrado em Linguística). Brasília, Universidade de Brasília, 2010.

QUADROS, Ronice Müller. Aquisição de L1 e L2: o contexto da pessoa surda. In: Anais do Seminário Desafios e Possibilidades na Educação Bilíngue para Surdos. Rio de Janeiro: INES, 1997.

QUADROS, Ronice Müller; KARNOPP, Lodenir B. Lingua de Sinais brasileira: estudos linguísticos. Porto Alegre: Artmed, 2004.

ROCHA, Décio O. S. A natureza do signo linguístico. In: CARNEIRO, Marísia (Org.). Pistas e travessias. Rio de Janeiro: EdUerj, 1999. 
ROCHA, Décio O. S. O linguístico e o extralinguístico. In: CARNEIRO, Marísia (Org.). Pistas e travessias. Rio de Janeiro: EdUerj, 1999.

RODRIGUES, Isabel Cristina. Debates em educação bilíngue para surdos: vozes que habitam o dizer "não". Dissertação (Mestrado em Letras) - Rio de Janeiro, UERJ, 2002.

ROSA, Maria Carlota. Introdução à morfologia. São Paulo: Contexto, 2000.

SANDMANN, Antônio. Morfologia lexical. 2.ed. São Paulo: Contexto, 1997.

SILVA, Nilce Maria. Instrumentos linguísticos de Lingua Brasileira de Sinais: constituição e formulação. 2012. Tese (Doutorado em Linguística). Campinas, Unicamp, 2012.

STROBEL, Karin. As imagens do outro sobre a cultura surda. 2.ed. Florianópolis: Ed. da UFSC, 2009.

VILELA, Mário. O léxico do português: perspectivação geral. Confluência, Rio de Janeiro, n.8, p.17-30, 20 sem. 1994.

Data de submissão: 26/02/2014. Data de aprovação: 17/05/2014. 